\title{
DESAIN RUMAH BUDAYA \\ PASAR GEDHE HARDJONAGORO SEBAGAI DESTINASI PARIWISATA KOTA SOLO
}

\author{
Ahmad Fajar Ariyanto \\ Institut Seni Indonesia (ISI) Surakarta \\ Jalan Ki Hajar Dewantara No. 19 Kentingan, Jebres Surakarta \\ Email: leahfajar@yahoo.com
}

\begin{abstract}
This article is the research result of Interior Design Pasar Gedhe Hardjonagoro: Tourism Destination that Represents Cultural House in Solo City. This research is about an effort in rehabilitation program to maintain cultural heritage building that function as Traditional Market with the best featured products. The zoning and grouping are not well planned that it causes problems to the hierarchy of space. The circulation provides less accessibility for visitors, traders, distribution of goods, and waste. The research uses descriptive analytic method and design approach as design solution. The results achieved are: The concept of interior design revitalization of Pasar Gede Hardjonagoro aims to re-mapping the needs of interior design patterns for traders and visitors and provide an alternative offer of a functional, attractive design that resulting in increase of sales ratio. To achieve this goal, the design idea refers to functional, effective and efficient aspects that aesthetically adopt some architectural elements of Pasar Gede Hardjonagoro as a thematic approach.
\end{abstract}

Keywords: Pasar Gedhe Hardjonagoro Revitalization, Tourism Destination, functional design, Cultural House.

\section{PENDAHULUAN}

Dalam konteks pembangunan Kota Surakarta, pariwisata diharapkan mampu menjadi generator untuk mengembangkan perekonomian daerah, merevitalisasi budaya lokal, dan melestarikan pasar tradisional. Harapannya langkah tersebut berpeluang untuk meningkatkan kesejahteraan masyarakat. Kenyataannya peluang dan potensi keanekaragaman pasar tradisional tersebut belum menjadi perhatian khusus dan dimanfaatkan secara optimal sebagai dasar pengembangan pariwisata dan daya saing daerah Kota Solo. Pemanfaatan secara optimal tersebut juga belum dilakukan untuk Pasar Gedhe Hardjonagoro, yang disebut sebagai ikon jantung kota pada City Vision Profile.

Kementerian Pariwisata RI melalui Asisten Deputi Pengembangan Destinasi Wisata Budaya Deputi Bidang Pengembangan Destinasi dan Industri Pariwisata sedang mempersiapkan Kota Surakarta untuk fokus dalam Program Percepatan Pengembangan wisata Sejarah, Religi, Budaya, dan Tradisi. Program tersebut disosialisasikan pada tanggal 20 Oktober 2017 di Hotel Sunan, Surakarta. Pasar Gedhe Hardjonagoro memiliki potensi untuk menjadi bagian dari program tersebut. Nilai sejarah, budaya dan tradisi pasar tersebut bermakna sebagai heritage life bagi kota dan masyarakatnya.Heritage life tersebut perlu untuk diteliti lebih dalam tentang fasilitas bangunan dan pendukungnya, baik yang sifatnya negatif maupun positif.

Di samping potensi pasar tradisional sebagai 
representasi rumah budaya dan destinasi pariwisata, pasar tradisional tidak dipungkiri jika identik dengan ketidakteraturan, kumuh, sumber kemacetan, menyebarkan bau tidak sedap, becek, padat, penataan produk yang melanggar batas area. Meskipun sebenarnya esensi berbelanja di pasar tradisonal dapat menjadi daya tarik wisata, yaitu: interaksi sosial atau bersosialisasi sekaligus berekreasi. Dua halyang bertolak belakang tersebut juga terjadi di Pasar Gedhe Hardjonagoro, maka sudah selayaknya jika pemerintah kota melakukan revitalisasi tidak hanya pada kawasan, namun juga pada fasilitas berdagang dengan perspektif desain interior dan disertai program pelatihan serta pendampingan bagi para pedagang. Namun dalam program revitalisasi belum menyentuh perspektif desain interior. Padahal fasilitas area berdagang merupakan jantung transaksi ekonomi, interaksi sosial, dan representasi budaya masyarakat Solo. Sebagaimana diketahui Pasar Gedhe Hardjonagoro sebagai simbol alkuturasi budaya Cina, Jawa, dan Eropa sejak proses pertama pasar ini lahir pada masa Pakubuwana X. Berdasarkan hal tersebut maka narasi sosial budaya yang terjadi setiap hari di pasar ini harus didukung oleh pembagian area berdagang atau zoning dan grouping sesuai produk komoditi, sirkulasi, dan lain-lain, baik diPasar Gedhe Hardjonagoro sisi timur maupun sisi barat.

Beberapa hasil dari penelitian para akademisi, Munirwanto ${ }^{1}$ Pasar Gedhe termasuk salah satu dari 5 pasar yang dapat menjadi alternatif destinasi pariwisata. Penelitian tersebut merekomendasikan aspek sejarah dan arsitektur serta kuliner dari Pasar Gedhe Harjonagoro berpotensi untuk dikembangkan untuk aktifitas wisata. Namun dari hasil penelitian tersebut, belum ada yang membawa pasar dalam kerangka budaya dengan perpektif desain interior. Situasi dan kondisi interior dan para pedagang yang seperti apa yang mampu mendukung Pasar Gedhe Hardjonagoro sebagai destinasi pariwisata belum menjadi fokus penelitian sebelumnya.

Hasil dari riset ${ }^{2}$, tingkat aksesibilitas terhadap lokasi dapat mudah dijangkau menggunakan kendaraan pribadi maupun angkutan umum. Permasahahan yang terjadi pada site adalah rawan terjadi kemacetan disisi barat karena parkir masih di badan jalan, tidak hanya pada satu ruas jalan, tetapi dua sisi jalan kanan dan kiri dipergunakan untuk parkir kendaraan. Lingkungan pasar masih terlihat sangat kumuh dan banyak sampah berserakan hingga ke jalan.

Dari sisi Desain Interior terdapat permasalahan, di antaranya adalah sistem grouping dan zoning pada Pasar Gede Hardjonagoro di Surakarta adalah belum dipisahkan hierarki secara jelas antara area publik dengan area servis.Sistem grouping dan zoning juga menimbulkan banyak saleable area menjadi ruang yang tidak produktif. Sistem zonasi juga belum mempertimbangkan frekuensi kegiatan, sehingga area-area dengan tingkat aktifitas rendah menjadi tempat untuk menumpuk barang yang pada akhirnya mengganggu sirkulasi. Pengelola pasar belum konsisten dan tegas dalam membagi tempat berdagang.

Existing arsitektur Pasar Gede Hardjonagoro sebenarnya sudah menyediakan elemen penunjang tata kondisi interior tersebut, namun karena rehabilitasi atau renovasi menerapkan sistem layout dengan partisi ruang secara masif maka tata kondisional gedung menjadi tidak sehat dan tidak berfungsi dengan baik. Berdasarkan kebutuhan tersebut maka penelitian desain interior Pasar Gedhe Hardjonagoro baik sisi barat maupun sisi timur sangat penting untuk dilakukan, karena hasilnya dapat memberikan kontribusi nyata bagi kota.

Layout pada interior Pasar Gede Hardjonagoro pada sisi Timur sejak awal direncanakan dengan memisahkan antara area sirkulasi dengan area penjualan. Pemisahan area tersebut dapat dilakukan dengan membuat perbedaan ketinggian lantai, lantai pada area penjualan ditinggikan sekitar $70 \mathrm{~cm}$ dari lantai area sirkulasi. Selain untuk menjaga kondisi lingkungan area penjualan tetap kering, perlindungan terhadap produk penjualan agar tidak mudah rusak, memberikan batas antar kios juga memberikan kenyamanan orientasi pandang bagi pembeli dalam memilih produk. Kondisi saat ini sangat berbeda dengan pertimbangan awal di atas, jalur sirkulasi dipenuhi dengan barang, batas ketetapan antar kios terhalang oleh barang yang menumpuk sehingga menimbulkan ketidakteraturan. Layout diatur dengan 
cara memisahkan berdasarkan jenis barang dagangan juga sudah dilakukan, namun dalam pelaksanaannya masih terdapat beberapa jenis barang yang tidak sesuai dengan penempatannya.

Sirkulasi Pasar Gede Hardjonagoro sisi Barat dan Timur saat ini kurang memberikan aksesibilitas yang baik bagipengunjung, pedagang maupun dalam pendistribusian barang. Pemisahan area sirkulasi penjualan dengan sirkulasibarang (servis) juga belum dilakukan, baik dengan adanya perbedaan lebar jalur sirkulasi maupun penyediaan jalur khusus. Saat ini pedagang buah Pasar Gede Hardjonagoro menggunakan bekas kemasan buah sebagai display dagangannya, sehingga permasalah klasik muncul kembali yaitu ketidakteraturan, kumuh, padat, dan penataan produk yang melanggar batas area.

Treatment pada lantai adalah dengan kenaikan level lantai pada area penjualan sekitar $20 \mathrm{~cm}$ pada pasar sisi barat dan $60 \mathrm{~cm}$ pada pasar sisi timur dengan tujuan memisahkan antara area display dengan area sirkulasi atau membuat batas imajiner terhadap batas kios. Kelemahan treatment ini adalah pengunjung atau pembeli kurang dapat leluasa dalam mengamati dan memilih produk dagangan, dari sisi pedagang juga cukup sulit untuk memberikan pelayanan kepada calon pembeli. Ruang menjadi lebih sempit sehingga interaksi antara calon pembeli dan pedagang jadi kurang nyaman.

Keputusan desain dinding pada rehabilitasi atau renovasi Pasar Gede Hardjonagoro sisi barat adalah dengan membagi setiap kios dengan dinding partisi yang masif menggunakan batu bata. Keuntungan dari keputusan ini adalah masing-masing kios memiliki privasi yang baik, dari sisi keamanan desain ini memberikan perlindungan yang sangat baik terhadap barang dagangan. Masing-masing kios dilengkapi dengan pintu rollingdoor sebagai pengamanan disaat kios tutup. Namun keputusan desain dinding masif ini menimbulkan masalah lain, yaitu ruang-ruang di dalam bangunan pasar menjadi sulit untuk diakses oleh pengunjung. Treatment dinding ini juga membuat ruang-ruang yang berada didalam menjadi gelap dan minimnya sirkulasi udara sehingga menimbulkan ketidaknyamanan baik secara fisik maupun psikis.

Ketinggian ceiling pada Pasar Gede Hardjonagoro adalah $437 \mathrm{~cm}$ dengan mengekpose ducting lantai atas dicat warna putih dan warna cream pada balok-balok strukturnya. Upaya ini sangat efisien dalam pembiayaan pekerjaan karena tidak perlu pengadaan material penutup ceiling beserta pelaksanaan konstruksinya. Namun perencanaan yang kurang cermat mengakibatkan titik-titik peletakan fixture ceiling seperti lampu menjadi kurang fleksibel, sehingga untuk penambahan fixture menjadi kurang rapi dan membahayakan keamanan bangunan maupun pelaku aktifitas di dalamnya.

Penelitian fokus pada penciptaan alternatif desain interior sehingga Pasar Gedhe Hardjonagoro sebagai ikon jantung kota layak disebut sebagai destinasi pariwisata Kota Solo yang merepresentasikan rumah budaya.

\section{METODE}

Penelitian dilakukan di Pasar Gedhe Hardjonagoro, jalan Urip Sumoharjo, kota Surakarta. Jangka waktu penelitian selama enam bulan, teknik pengumpulan data dengan wawancara dan observasi. Bantuan alat perekam suara untuk wawancara dan kamera sebagai pendukung pengumpulan data. Leica disto sebagai alat ukur untuk menggambar ulang denah, program ruang area pedagang dan pembeli serta kebutuhan data ruang gerak lebih akurat.Analisis data dilakukan secara deskriptif kualitatif dan interpretatif. Analisis data dilakukan dengan cara mengatur secara sistematis pedoman wawancara, data kepustakaan, kemudian memformulasikan secara deskriptif, selanjutnya memproses data dengan tahapan reduksi data, menyajikan data, dan menyimpulkan.Alternatif desain interior didasarkan pada pembangunan area publik yang didasari pada pertimbangan secara menyeluruh, penyediaan sarana dan prasarana belum menjadi jaminan keberhasilan. Perencanaan desain yang matang khususnya pada subtansi pemrograman desain yang meliputi faktor manusia (human factor), faktor fisik (physical factor) dan faktor lainnya ${ }^{3}$. Kebutuhan dan keinginan masyarakat dapat dijawab melalui pendekatan pemecahan desain untuk menghasilkan keputusan desain yang baik.

Pendekatan pemecahan desain adalah seperangkat teori yang dirumuskan berdasarkan 
landasan teori dan kreativitas untuk memecahkan desain atau menemukan desain yang tepat ${ }^{4}$. Perancangan tata display rehabilitasi desain interior Pasar Gede Hardjonagoro di Surakarta akan menggunakan beberapa pendekatan desain yaitu pendekatan fungsi, pendekatan ergonomi dan pendekatan estetika.

\section{HASIL DAN PEMBAHASAN}

\section{A. Proses Analisis Desain}

\section{AnalisisPola Aktifitas dan Kebutuhan Ruang}

Pola aktifitas terdiri dari beberapa aktifitas yang akan dibedakan menurut pengguna (manusia) dan barang. Aktifitas pengguna (manusia) terdiri dari aktifitas pengunjung, pedagang, dan pengelola. Aktifitas barang terdiri atas barang dagangan dan pengelolaan sampah. Idealnya aktifitas manusia dan barang dirancang secara terpisah sehingga tidak terjadi sirkulasi silang. Pemisahan tersebut dapat dilakukan dengan secara fisik memisahkan jalur pola sirkulasi maupun pola hubungan antar ruang atau dapat pula memisakan berdasarkan waktu kegiatan operasionalnya. Berikut penjelasan bagan alur aktifitas berdasarkan alur kegiatan manusia (pengunjung, pedagang dan pengelola) dan barang (dagangan dan pengelolaan sampah) terkait dengan interaksi terhadap kebutuhan ruang sebagai berikut,

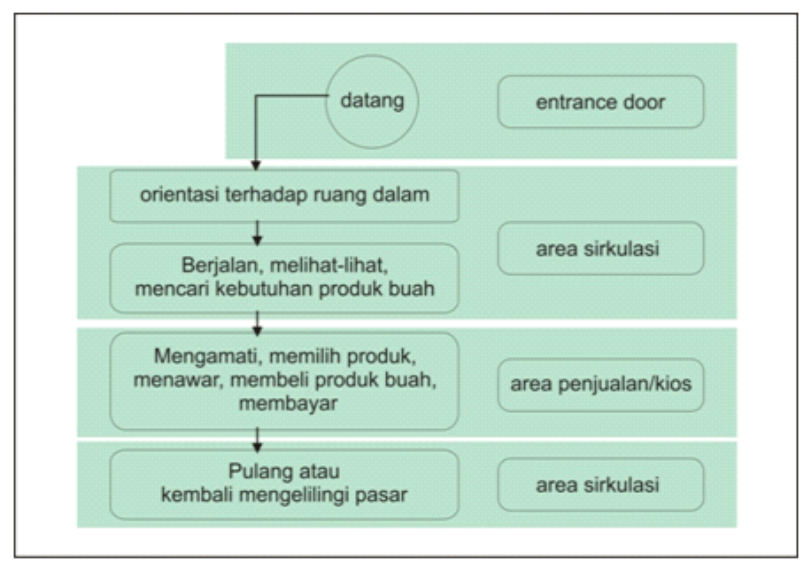

Gambar 1. Alur Kegiatan Pengunjung

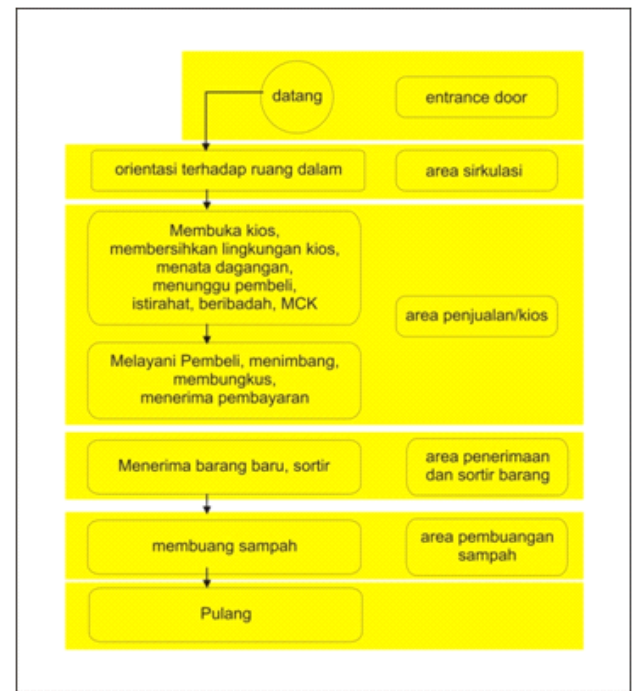

Gambar 2. Alur Kegiatan Pedagang

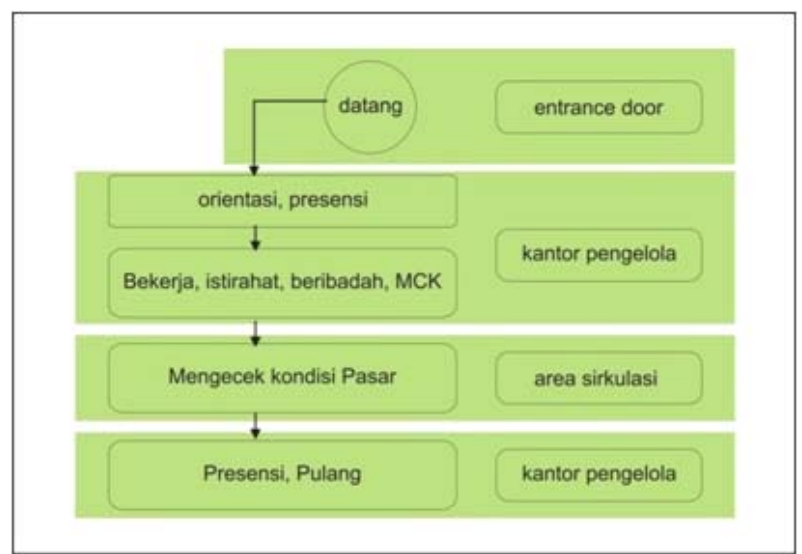

Gambar 3. Alur Kegiatan Pengelola

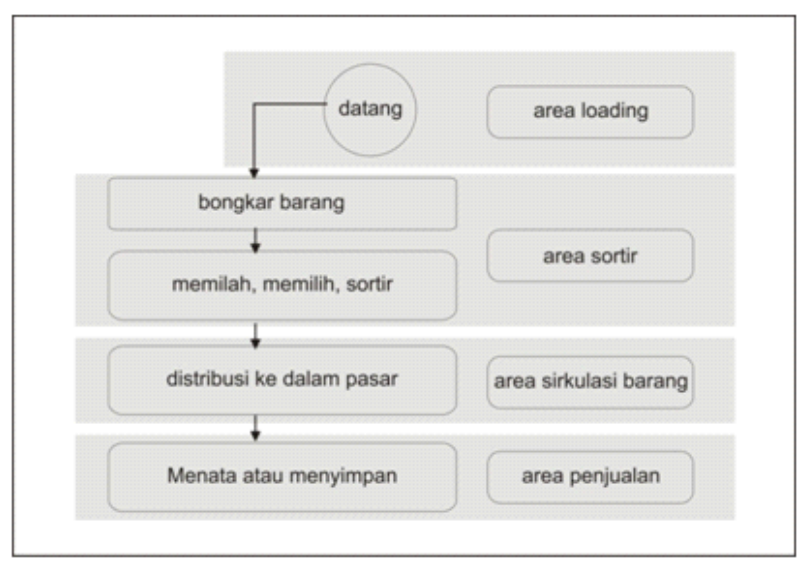

Gambar 4. Alur Barang

\section{Analisis Besaran Ruang}

Ruang interior terbentuk dari sistem struktur bangunan yang dipertegas dengan elemen lantai, dinding dan langit-langit. Setiap bangunan 
mempunyai pola yang dapat dikenali dari elemenelemen dan sistem tersebut. Masing-masing pola memiliki bentuk geometris awal yang kemudian menurunkan dan membentuk suatu volume ruang berdasarkan kesamaannya ${ }^{5}$. Kebutuhan luas ruang dapat diperkirakan dari analisis jumlah orang yang dilayani, peralatan ruang yang dibutuhkan, dan sifat aktifitas yang akan berlangsung di setiap ruang. Berdasarkan dokumen as built drawing Pekerjaan Rehabilitasi Pembangunan Pasar Gedhe Barat Lanjutan 2015, besaran kios pedagang dapat diidentifikasi menjadi beberapa tipe sesuai dengan volume ruangnya,

a. Tipe A, ukuran kios berkisar $200 \times 150 \mathrm{~cm}$

b. Tipe B, ukuran kios berkisar $200 \times 200 \mathrm{~cm}$

c. Tipe C, ukuran kios berkisar 200 × $90 \mathrm{~cm}$

d. Tipe D, ukuran kios berkisar $270 \times 90 \mathrm{~cm}$

e. Tipe E, ukuran kios berkisar $200 \times 80 \mathrm{~cm}$

Tipe berdasarkan besaran ruang kios selanjutnya akan menjadi dasar pada tahap selanjutnya, terutama pada layout dan standar ukuran bagi penyediaan display penjualan.

Besaran kios pada Pasar Gede sisi Timur disusun berdasarkan sistem layout dengan jenis grid dan kolom. Sistem ini dipilih untuk memberikan kemudahan terhadap aksesbilitas sirkulasi, membedakan fungsi ruang (ruang sirkulasi dan ruang penjualan), fleksibilitas terhadap kebutuhan volume kios, dan kemudahan pembagian fungsi masingmasing ruang. Lebar area penjualan masing-masing $3 \mathrm{~m}$ double loaded (dua sisi) memanjang terbagi oleh area sirkulasi $192 \mathrm{~cm}$

\section{Analisais Grouping dan Zoning}

Pada tahap grouping dan zoning dapat disimpulkan pemetaan area penjualan, area servis dan area sirkulasi. Dimensi dan zoning area penjualan berdasarkan pada data pembagian kios yang telah dilakukan oleh Dinas Pengelola Pasar Kota Surakarta. Dimensi dan zoning area servis berdasarkan pada kondisi existing dan data dokumen as built drawing Pekerjaan Rehabilitasi Pembangunan Pasar Gedhe Barat Lanjutan 2015. Dimensi dan zoning area sirkulasi dipetakan kembali dengan memperlebar area sirkulasi pada entrance loading barang dan keluar barang dari $180 \mathrm{~cm}$ menjadi $225 \mathrm{~cm}$ yang kemudian dibulatkan menjadi $220 \mathrm{~cm}$ karena pertimbangan pemakaian ukuran bahan lantai $20 \times 20 \mathrm{~cm}$. Cross Circullation antara area loading barang, sirkulasi pengunjung dan sirkulasi pedagang diselesaikan dengan memberikan sirkulasi cabang melalui interroom. Berikut hasil analisa grouping dan zoning,

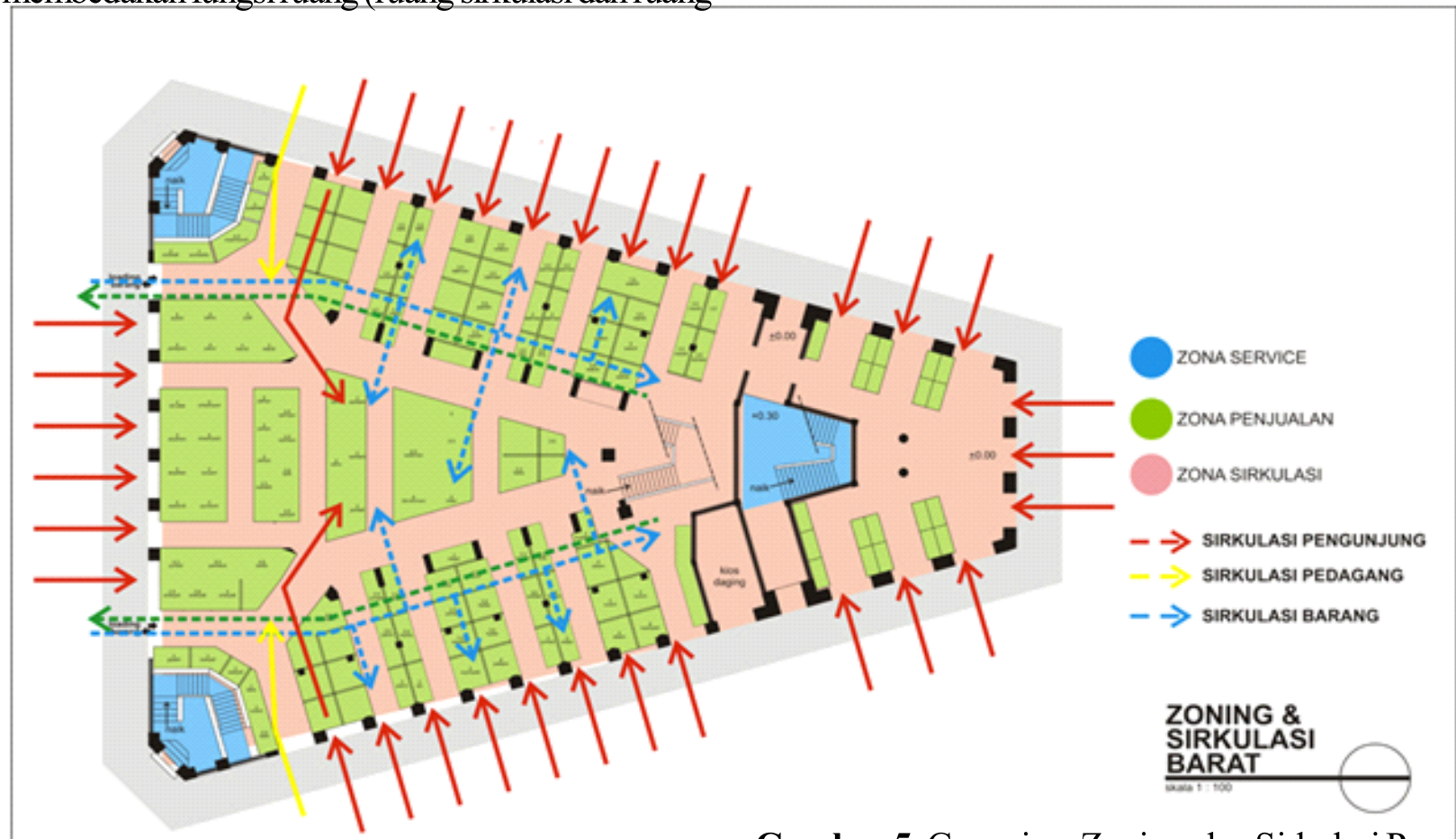

Gambar 5. Grouping, Zoning, dan Sirkulasi Pasar Gede sisi Barat 


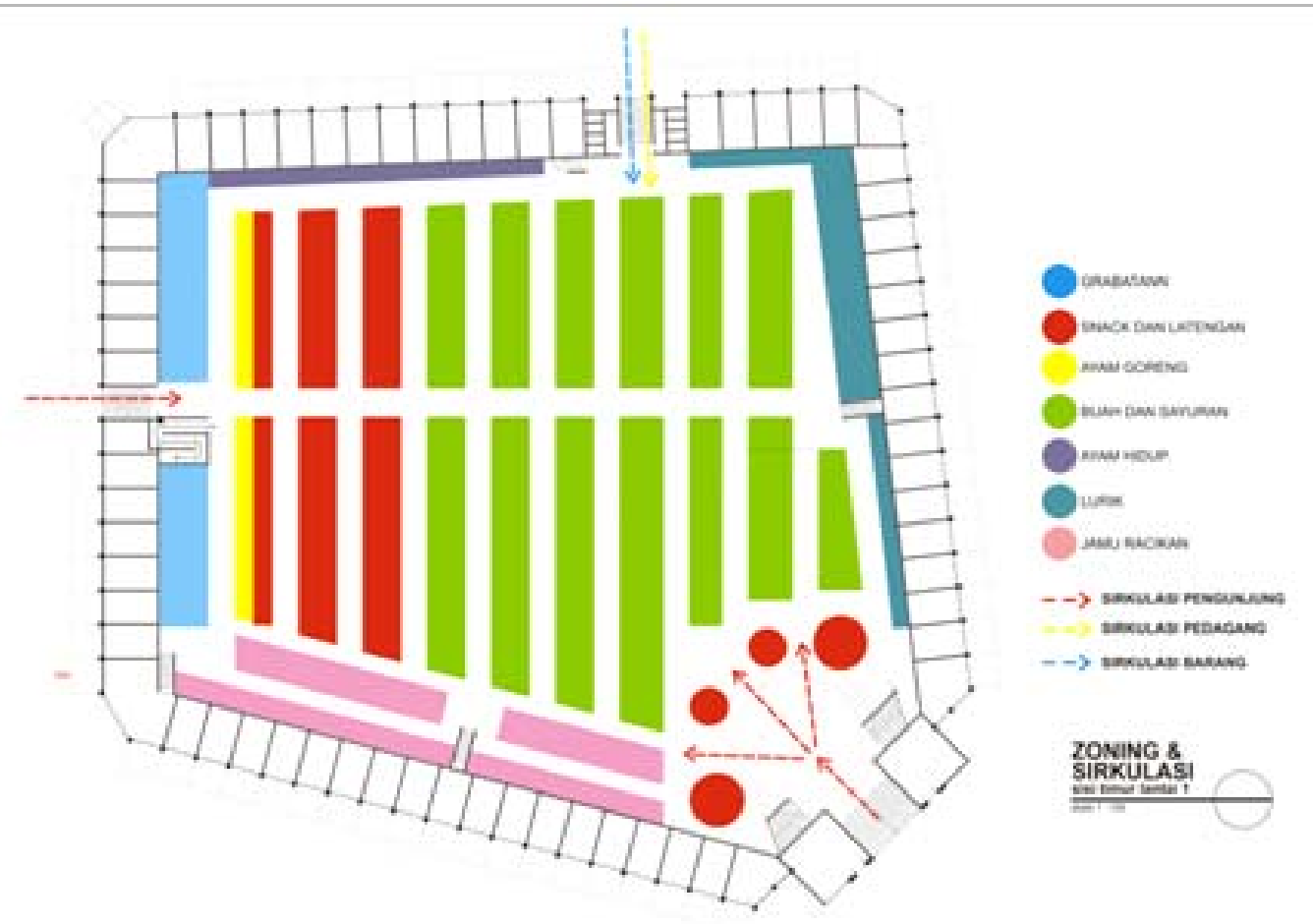

Gambar 6. Zonasi Berdasarkan Jenis Komoditi serta alur sirkulasi Pasar Gede sisi Timur Lantai 1

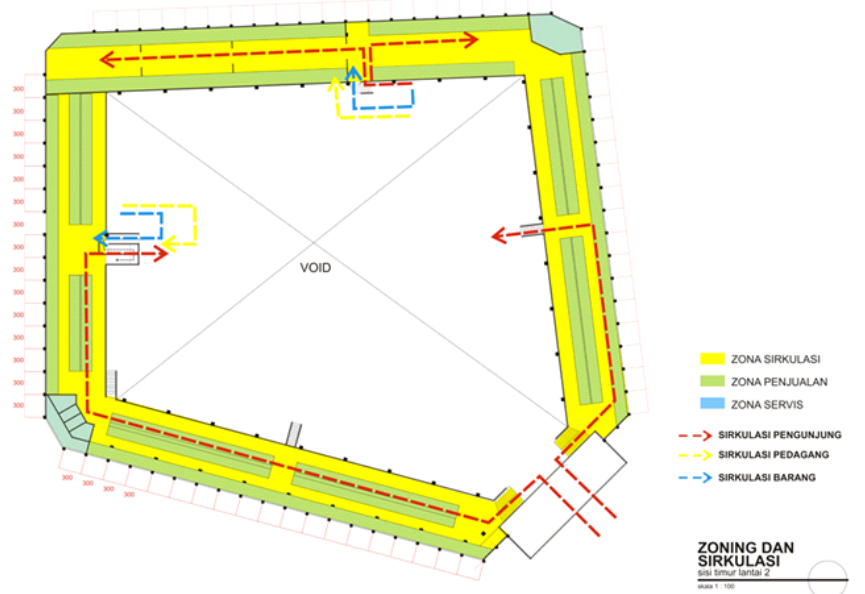

Gambar 7. Zonasi Berdasarkan Jenis Komoditi dan sirkulasi

Pasar Gede sisi Timur Lantai 2

\section{Analisis Sirkulasi}

Berdasarkan analisa pelaku kegiatan, pola aktifitas dan kebutuhan ruang maka sirkulasi pada rehabilitasi interior Pasar Gede Hardjonagoro di
Surakarta dibagi menjadi 4 (tiga) macam yaitu,

a. Sirkulasi Pengunjung atau calon pembeli

b. Sirkulasi Pedagang

c. Sirkulasi Barang (Produk)

d. Sirkulasi Sampah

Sirkulasi yang baik adalah sirkulasi yang sederhana, memiliki keluasan yang cukup nyaman untuk sirkulasi dua arah. Keluasan dibutuhkan agar pelaku aktifitas tidak saling berhimpitan satu dengan yang lain. Pada sirkulasi pendistribusian barang membutuhkan keluasan yang lebih besar.

Perencanaan sistem sirkulasi diatas merupakan hasil dari analisa berdasarkan,

\section{a. Aksesibilitas dan Sistem Sirkulasi}

Tujuan perencanaan aksesbilitas dan sistem sirkulasi adalah menjamin semua kios pasar dapat dijangkau oleh pengunjung. Pintu masuk dan hierarki sirkulasi harus dirancang agar semua area pasar mudah dijangkau. Zone komoditas inti ditempatkan pada area tertentu agar dapat menarik pengunjung untuk menghidupkan zone komoditas lainnya. Kios-kios harus mendapatkan aksesibilitas visual yang memadai dari pengunjung. Kemudahan orientasi pengunjung didalam pasar dengan merancang jalur sirkulasi secara hierarkis 
dan menyediakan simpul-simpul sirkulasi pada jalur yang panjang

\section{b. Efektifitas Pemanfaatan Ruang}

Tujuan efektifitas pemanfaatan ruang dalam perencanaan sirkulasi adalah mengoptimalkan proporsi luas ruang yang dapat dijual (saleable area). Luas saleable area minimum $65 \%$ dari luas keseluruhan bangunan dan jalur sirkulasi dapat dioptimalkan dengan penerapan sistem double loaded (pelayanan dalam dua sisi).

\section{c. Lebar Jalur Sirkulasi}

Lebar jalur sirkulasi diperoleh dengan menentukan lebar jalur sirkulasi secara efisien namun tetap nyaman. Jalur-jalur sirkulasi dirancang agar pengunjung bisa menikmati suasana pasar. Lebar jalur sirkulasi minimal bisa dilewati dua orang dan maksimal $30 \%$ dari jumlah lebar kios yang diapitnya.

Berdasarkan uraian diatas maka keluasan/ lebar jalur sirkulasi adalah sebagai berikut,

a. Lebar jalur sirkulasi pengunjung pada cabang / simpul sirkulasi adalah $160 \mathrm{~cm}$

b. Lebar jalur sirkulasi utama dengan kemungkinan pelaku aktifitas pedagang, pengunjung dan barang adalah $240 \mathrm{~cm}$

c. Lebar jalur distribusi barang dan jalur pengelolaan sampah $220 \mathrm{~cm}$.

\section{Analisis Layout}

Layout disusun berdasarkan analisa pelaku kegiatan, pola aktifitas, kebutuhan ruang, jenis produk dan sirkulasi. Layout dengan sistem terbuka akan memberikan tingkat kemudahan aksesbilitas visual dan pembentukan tapak sirkulasi yang logis. Layout dengan sistem terbuka akan menciptakan interaksi yang baik antara pedagang dengan pengunjung sehingga ruang sosio-kultural sebagai pasar tradisional dapat hidup kembali. suasana tawar menawar (sliding price) dan model basar (bazaar type economy) yang memberi nuansa khas yaitu berbelanja sekaligus bersosialisasi dan rekreasi. Nuansa seperti inilah yang akan menjadi daya tarik bagi para wisatawan.

\section{Analisis Lantai}

Lantai pada pasar sisi barat menggunakan material terazzo berukuran $20 \times 20 \mathrm{~cm}$ dengan warna merah maroon. Pertimbangan pemilihan material terazzo adalah material ini memiliki porousitas yang tinggi dan memiliki sifat kapasitif sehingga dapat mereduksi panas didalam ruangan. Warna merah maroon dipilih dengan pertimbangan mereduksi radiasi sinar matahari dan menghidari terjadinya silau pada mata. Pemilihan material terazzo juga bertujuan untuk mendukung penciptaan suasana atau tema. Treatment pada lantai menggunakan beberapa metode yaitu penerapan pola lantai pada beberapa area. Pola lantai ini diaplikasikan dengan tujuan untuk mempermudah pekerjaan pada pertemuan arah pasangan dari berbagai arah mengingat posisi existing bangunan pada sisi Timur dan Barat miring 16 derajat. Pertemuan sudut antara 90 derajat dan 16 derajat inilah yang akan menimbulkan masalah dari sisi teknis pemasangan. Pola lantai menggunakan tenik cor ditempat dengan bahan terazzo dengan motif batik kawung. Selain berfungsi sebagai stopper pasangan lantai motif ini difungsikan sebagai penanda atau petunjuk area.

Pola lantai ini diaplikasikan dengan tujuan untuk mempermudah pekerjaan pada pertemuan arah pasangan dari berbagai arah mengingat posisi existing bangunan pada sisi Timur dan Barat miring 16 derajat. Pertemuan sudut antara 90 derajat dan 16 derajat inilah yang akan menimbulkan masalah dari sisi teknis pemasangan. Pola lantaimenggunakan tenik cor ditempat dengan bahan terazzo dengan motif batik kawung. Selain berfungsi sebagai stopper pasangan lantai motif ini difungsikan sebagai penanda atau petunjuk area.

Lantai pasar sisi timur menggunakan materialfloor hardener, dengan pertimbangan kebutuhan, aktifitas yang sangat kompleks dan jenis komoditi yang sangat beragam. Kriteria pemilihan material tersebut memiliki kemudahan dalam perawatan, kuat, tahan gesek, tahan benturan, tidak licin, tidak mudah berjamur, tidak mudah berlumut, tahan api dan memiliki tingkat pourusitas material ang cukup rendah. Apabila dibandingkan dengan saat ini, lantai pada sisi timur menggunakan material keramik warna putih dan sebagian menggunakan material terrazzo tekstur warna abu-abu menimbulkan permasalahan popping pada keramik dan sulitnya membersihkan pada terrazzo tekstur. Terazzo tekstur secara teknis dipilih agar lantai tidak licin, namun kelemahan dari 
jenis ini sangat sulit untuk dibersihkankarena kotoran akan mengisi pada celah tekstur tersebut. Leveling lantai pada pasar sisi timur juga menjadi perhatian karena kurang membertimbangkan sirkulasi pembuangan air kotor (baik limbah komoditi maupun maintenance kebersihan).

\section{Analisis Ceiling}

Ceiling pada pasar sisi barat menggunakan material gypsumboard yang dipasang flush tanpa adanya nat pada sambungan. Finishing ceiling menggunakan cat tembok warna putih. Pertemuan antara ceiling dan dinding menggunakan cornice dengan material gypsum precast, dengan finishing menggunakan cat tembok warna putih. Selain berfunsi sebagai penutup ruang bagian atas, ceiling juga berfungsi untuk menempatkan beberapa fixture pencahayaan, instalasi listrik dan pemasangan speaker. Desain pencahayaan terdiri atas dua jenis yaitu pencahayaan secara merata pada jalur sirkulasi dan pencahayaan secara khusus (task lighting) pada area penjualan/display. Pencahayaan secara merata menggunakan armatur down light dan pendant light (lampu gantung) dengan menggunakan lampu jenis SL 23W, warm light. Pencahayaan pada area display menggunakan armatur downlight dengan jenis lampu yang sama. Dipilih menggunakan armatur downlight dengan pertimbangan mampu merefleksikan penyebaran cahaya secara merata dan tidak menimbulkan efek silau pada mata. Warna pencahayaan menggunakan natural warm dengan pertimbangan secara visual tidak merubah warna produk buah atau memendarkan warna asli dari produk buah tersebut. Berikut hasil analisa rencana ceiling pada interior Pasar Gedhe Hardjonagoro sisi barat,

Ceiling pada pasar sisi timur tetap menggunakan ceiling existing karena memiliki utilitas yang sangat baik selain tidak merubah originalitas rancangan struktur atap bangunan cagar budaya. Struktur atap jack roof dengan perletakan outlet pada atap. Lubang antara atap induk dengan atap 'topi' pada jack roof terdapat kisi-kisi sebagai bukaan keluarnya udara (outlet). Posisi outlet pada atap ini lebih efektif untuk mengeluarkanudara panas yang banyak berkumpul di bagian atas ruangan tersebut.Desain pencahayaan pada pasar sisi timur menggunakan general lighting yang ditempatkan secara merata baik pada jalur sirkulasimaupun pada area penjualan. Armatur yang digunakan adalah jenis pendant/sistem gantung dengan menggunakan lampu jenis mercury.

\section{Analisa Dinding}

Berdasarkan hasil observasi dan analisa pada dinding, maka pada desain dinding penyekat antar kios akan diganti dengan bentuk terbuka atau desain dinding hanya sebagai partisi setinggi $90 \mathrm{~cm}$. Keputusan desain dinding mempertimbangkan bentuk layout dan display penjualan dengan sistem terbuka. Pengolahan pada dinding mengacu pada tema, beberapa elemen arsitektur yang khas pada Pasar Gedhe Hardjonagoro sisi barat diaplikasikan dengan pertimbangan estetis dan fungsional. Material dinding pada sisi atas menggunakan gypsum board dengan finishing cat tembok warna light cream, roster replika juga berfungsi sebagai media pendistribusian udara dari luar bangunan kedalam bangunan.pemakaian roster bertujuan untuk memperbesar outlet penghawaan alami, sehingga pendistribusian udara didalam ruangan akan lebih besar dan merata. Pada dinding kolom existing menggunakan treatment walldaddo dengan menempel ubin terazzo ukuran $20 \times 20 \mathrm{~cm}$, warna merah maroon setinggi $113 \mathrm{~cm}$, pada sisi bawah (skirting) menggunakan nat setinggi $13 \mathrm{~cm}$ dari permukaan lantai (floor finished level)

\section{Analisis Display}

Berdasarkan dokumen as built drawing Pekerjaan Rehabilitasi Pembangunan Pasar Gedhe Barat Lanjutan 2015, besaran kios pedagang dapat diidentifikasi menjadi beberapa tipe sesuai dengan volume ruangnya,

a. Tipe A, ukuran kios berkisar $200 \times 150 \mathrm{~cm}$

b. Tipe B, ukuran kios berkisar $200 \times 200 \mathrm{~cm}$

c. Tipe C, ukuran kios berkisar $200 \times 90 \mathrm{~cm}$

d. Tipe D, ukuran kios berkisar $270 \times 90 \mathrm{~cm}$

e. Tipe E, ukuran kios berkisar 200 × $90 \mathrm{~cm}$

Besaran ruang masing-masing tipe kios menjadi pertimbangan dimensi display, dan berdasarkan pada bentuk dan dimensi yang bervariasi tersebut maka sistem display yang paling menguntungkan adalah dengan sistem modular. Sistem modular akan dibagi menjadi dua jenis yaitu display yang berfungsi untuk memajang produk dan 
display yang berfungsi ganda untuk mewadadi kegiatan pelayanan seperti menimbang barang dagangan dan menyimpan beberapa barang pendukung. Dimensi standar modular untuk display dengan fungsi pelayanan atau memiliki fungsi sebagai tempat menaruh timbangan, dan tempat penyimpanan.

Material displaymenggunakan perpaduan besi (rangka utama), kayu pinus (case and table fixture), dan anyaman rotan sebagai penutup case fixturenya. Perpaduan beberapa jenis material ini bertujuan secara fungsional dan pencapaian tema. Display secara visual mempunyai ciri lokalitas dan mampu menjadi atraksi visual yang menariksehingga tercipta pengalaman ruang yang menarik bagi pengunjung pasar. Skema material dan bahan display adalah sebagai berikut,

Display tipe A,B,C dan D dapat dikombinasikan sesuai dengan kebutuhan luasan kios. Masing-masing mempunyai penutup yang terbuat dari anyaman rotan. Tutup tersebut dilengkapi dengan kunci, sehingga ketika kios tutup, pedagang dapat menutup dan mengunci tutup tersebut sebagai antisipasi keamanan terhadap barang dagangan. Tutup dengan material rotan dapat memberikan sirkulasi udara yang cukup sehingga produk buah tidak mudah busuk, menghindari dari serangga, dan tidak merubah warna maupun bau pada produk buah. Finishing kayu dan rotan menggunakan pelapisan cat natural waterbased, sehingga aman dan tidak mengakibatkan racun pada produk buah. Finishing rangka besi menggunakan cat enamel warna hitam.

\section{B. Konsep Desain Interior Pasar Gedhe Hardjonagoro sebagai Destinasi Pariwisata yang Merepresentasikan Rumah Budaya di Kota Solo}

Pasar Gede Hardjonagoro merupakan bangunan cagar budaya yang ditetapkan dengan Surat Keputusan (SK) Walikota Nomor 646101F/I/2012. Pasar Gede Hardjonagoro terletak di Jalan Urip Sumoharjo, Kelurahan Sudiroprajan, Kecamatan Jebres Surakarta. Pasar Gedhe Hardjonagoro sebagai tempat transaksi jual beli hasil bumi dan kebutuhan pokok, berdiri sejak pemerintahan Paku Buwono X, terdiri dari dua bangunan di sisi barat dan timur. Pasar Gedhe telah mengalami renovasi dan revitalisasi. Pemerintah Kota Surakarta telah merevitalisasi Pasar Gedhe sisi barat tahun 2015. Upaya revitalisasi tersebut sebagai wujud keberpihakan pemerintah kota terdapat masyarakat.Program rehabilitasi atau renovasi pasar tradisional, khususnya Pasar Gedhe sisi barat (pasar buah) di Surakarta hanya menyentuh infrastrukur bangunan. Ruang dalam sebagai tempat aktivitas bertemunya pedagang dan pembeli tidak menjadi bagian dari program rehabilitasi. Desain interior tidak menjadi perhatian, khususnya tata display atau teknik pajang produk. Program rehabilitasi hanya menyediakan tempat untuk pedagang agar dapat berjualan, dengan membagi area pedagang sebanyak berapa pedagang yang harus tertampung di dalam pasar.

Peraturan Menteri Perdagangan RI No: 70/M-DAG/PER/12/2013 tentang Pedoman Penataan dan Pembinaan Pasar Tradisional, Pusat Perbelanjaan dan Toko Modern pada bab V tentang Pengelolaan Pasar tradisional pasal 19 ayat 1 bagian c termuat, pengelola pasar tradisional memiliki peran antara lain dapat berupa melaksanakan pembinaan, pendampingan, dan pengawasan kepada para pedagang. Pada pasal 19 ayat (2), kegiatan pembinaan, pendampingan dan pengawasan kepada para pedagang sebagaimana dimaksud pada ayat (1) huruf c, dilakukan melalui (a) peningkatan pelayanan pada konsumen baik mengenai kualitas barang, kebersihan, takaran, kemasan, penyajian/ penataan barang maupun dalam pemanfaatan fasilitas ruang, (b) peningkatan kompetensi pedagang melalui pendidikan, pelatihan dan penyuluhan. Peraturan Menteri tersebut mewajibkan pengelola pasar untuk melibatkan para pedagang dalam tata kelola pasar melalui pembinaan dan pendampingan dalam rangka peningkatan kompetensi mereka. Upaya peningkatan pelayanan kepada konsumen di antaranya melalui penyajian/penataan barang atau tata display. Strategi tata display merupakan upaya produsen untuk mengelompokkan produk sesuai dengan jenisnya serta menyesuaikan harga dengan produknya. Strategi penataan display multak diperlukan agar konsumen memperoleh kesan bahwa barang yang tersedia selalu baru, baik dan menarik untuk dibeli oleh konsumen. Hal ini akan 
mempermudah proses selanjutnya bagi konsumen sebagai alat promosi dengan memberikan informasi pada orang-orang di sekitarnya.

Peran Pasar Gedhe tidak hanya sebagai tempat transaksi antara pedagang dan pembeli, namun juga sebagai destinasi pariwisata kota, sehingga kebutuhan tata kelola pasar khususnya tata display produk sangat penting untuk menarik para konsumen sekaligus wisatawan. Tata display yang baik dan menarik membawa dampak positif terhadap peningkatan penjualan, pendapatan pedagang, dan PAD Pemerintah Kota Surakarta. Berdasarkan kebutuhan tersebut maka penelitian ini sangat penting untuk dilakukan, ketika program rehabilitasi belum menyentuh tata display dan peningkatan kompetensi pedagang melalui pendampingan dan pelatihan.

Konsep revitalisasi desain interior Pasar Gede Hardjonagoro di Surakarta, bertujuan untuk memetakan kembali kebutuhan pola desain interior bagi pedagang maupun pengunjung/calon pembeli serta memberikan tawaran alternatif desain yang fungsional dan menarik sehingga berdampak pada peningkatan ratio penjualan. Untuk mencapai tujuan tersebut maka ide perancangan mengacu pada aspek fungsional, efektif dan efisien yang secara estetis mengadopsi beberapa elemen arsitektural Pasar Gede Hardjonagoro sebagai pendekatan tematiknya. Tujuan pengadopsian beberapa elemen arsitektur tersebut adalah untuk memperkuat dialog antara luar dan dalam bangunan, memproyeksikan sense of place Pasar Gede sebagai rumah budaya masyarakat Surakarta yang plural dan dinamis.

\section{Implementasi Konsep Desain Interior 1. Interior Area Penjualan}

Layout kios dengan sistem terbuka memudahkan orientasi pengunjung didalam pasar, sehingga kios-kios mendapatkan aksesibilitas visual yang memadai dari pengunjung. Pengunjung dengan mudah menjangkau kios-kios, sehingga setiap kios mempunyai kemungkinan ratio yang sama dalam penjualan. Layout dengan sistem terbuka juga mengoptimalkan jumlah proporsi luas ruang yang dapat dijual (saleable area). Zoning dan alur sirkulasi dapat dirancang dengan mempertimbangkan pengalaman ruang dan suasana yang menarik bagi pengunjung dengan menyediakan simpul-simpul sirkulasi pada jalur yang panjang. Jalur sirkulasi dioptimalkan dengan penerapan sistem double loaded (pelayanan dalam dua sisi). Ruang pasar secara psikologis tampak luas dan memberikan tata kondisional ruangan menjadi lebih baik. Penghawaan alami didistribusikan secara merata melalui rosterroster diatas kios dan pencahayaan dari lampulampu listrik tidak lagi terhalang oleh dinding kios. Pencahayaan melalui armatur downlight memberikan penyebaran cahaya yang merata dan tidak menyilaukan mata. Penambahan tingkat iluminasi pada setiap kios disamping mempertegas lokasi display juga memberikan efek cahaya yang baik bagi produk buah.

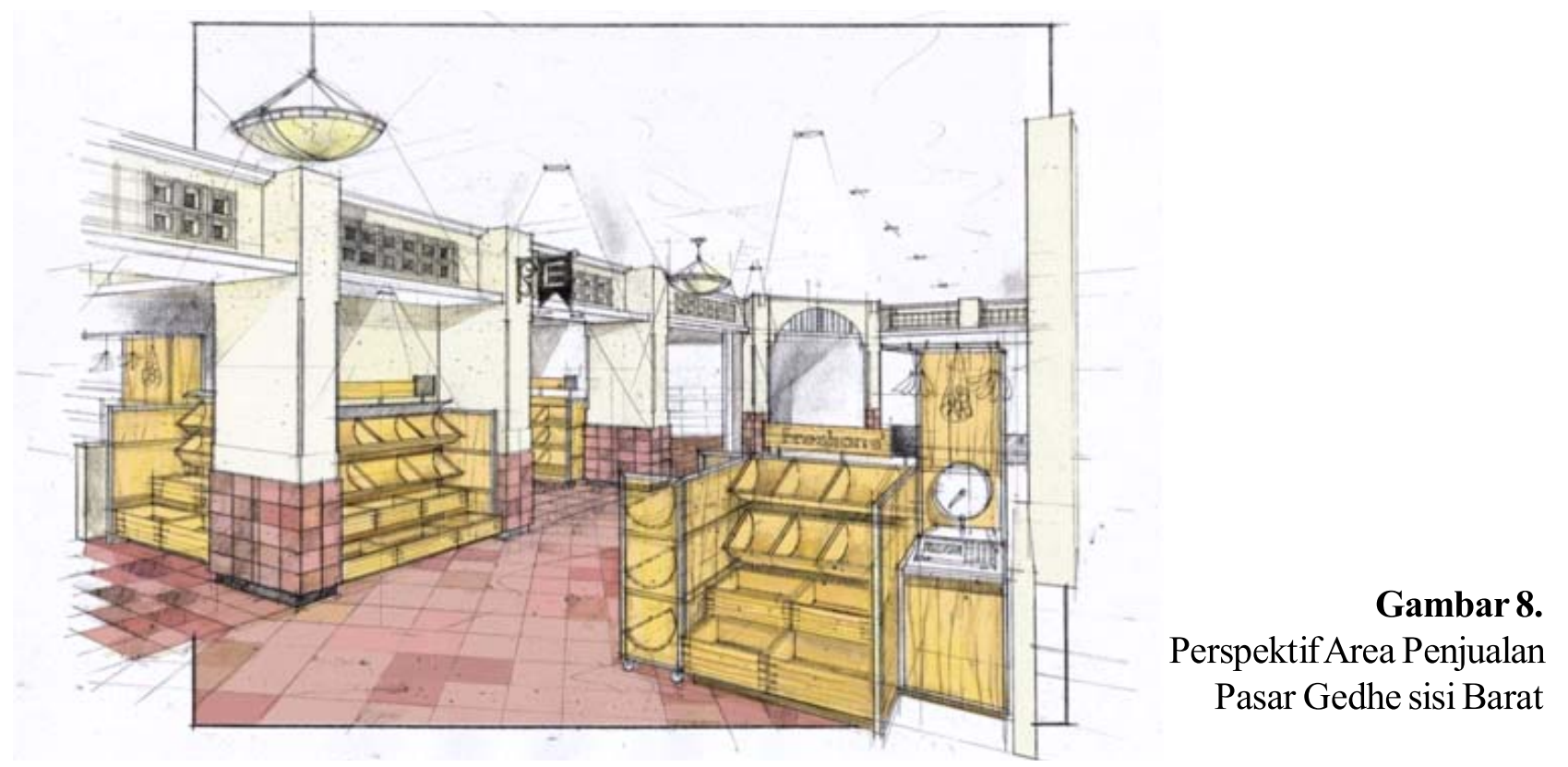




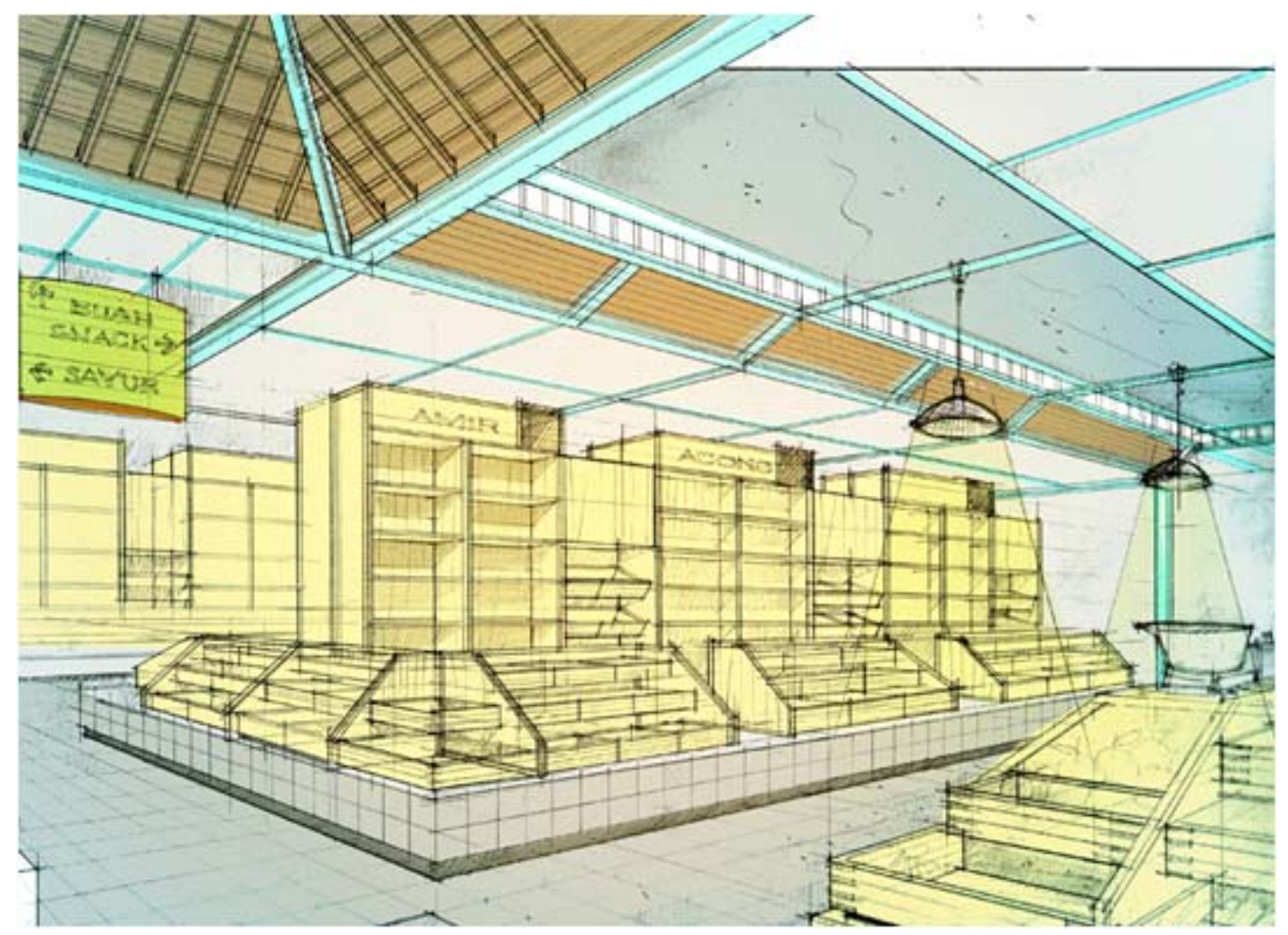

Gambar 9. PerspektifArea Penjualan

Pasar Gedhe sisi Timur Lantai Dasar

Pintu masuk dan hierarki sirkulasi harus dirancang agar semua area pasar mudah dijangkau. Display komoditas inti ditempatkan pada area tertentu agar dapat menarik pengunjung untuk menghidupkan zone komoditas lainnya. Rancangan dengan sistem terbuka menciptakan suasana interaksi sosiokultural. Ruang sosial terlihat dengan adanya ruang untuk berinteraksi sosial antara pengunjung, pedagang, dan pelaku lainnya. Sistem display terkait erat dengan sistem pelayanan dalam penjualan, karakteristik sistem pelayanan pada pasar tradisional adalah self selection atau pengunjung memilih sendiri barang yang akan dibeli dengan interaksi yang sangat dekat secara langsung dengan pedagang untuk tawar menawar. Kebutuhan ruang interaksi sosial seperti ini yang membedakan pasar tradisional dengan ruang pasar modern. Aktifitas memilih, menimbang berat, menanyakan harga, dan menawar harga adalah bentuk pelayanan secara personal yang memerlukan pendekatan desain display secara khusus. Misi perancangan pasar tradisional secara umum adalah menyediakan ruang-ruang yang nyaman, aksesibel, dan mewadahi interaksi sosial untuk aktivitas ekonomi dan sosial. Pasar menjadi tempat pedagang dalam mengembangkan diri.

Gaya atau tema interior dihadirkan dengan mengolah unsur pembentuk ruang, tata letak ruang, pengisi ruang, unsur dekoratif dan lain-lain. Pendekatan tema atau gaya pada penelitian ini memanfaatkan filosofi bentuk arsitektural Pasar Gedhe Hardjonagoro sisi barat dalam gubahan interiornya. Tujuan pendekatan tema ini adalah untuk mendukung terciptanya pengalaman ruang yang menarik bagi pengunjung pasar sehingga mampu memproyeksikan citra budaya Surakarta. Bentuk arsitektur yang berisi akulturasi budaya dalam kurun waktu sejarah akan diartikulasikan kedalam bentuk elemen-elemen interior. Beberapa bentuk elemen arsitektur Pasar Gede akan diaplikasikan kembali kedalam beberapa unsur pembentuk ruang. Tujuan pengadopsian beberapa elemen arsitektur tersebut adalah untuk memperkuat dialog antara luar dan dalam bangunan, memproyeksikan sense of place Pasar Gede dan citra budaya masyarakat Surakarta yang plural dan dinamis.

Pengadopsian bentuk arc (lengkung) yang menyatukan kolom di antara jalur sirkulasi, detail cantilever, roster, walldaddo pada kolom dengan 
penebalan lapisan terazzo membawa atmosfer luar kedalam interior. Pelaku aktifitas dibawa untuk merasakan suasana lokalitas yang khas yang merupakan cermin dari perjalanan sejarah Pasar Gedhe. Dinding menggunakan cat warna light cream tidak hanya memberikan psikologis ruang yang nampak luas tapi juga secara fungsional lebih menonjolkan produk buah. Pola lantai ini diaplikasikan dengan tujuan untuk mempermudah pekerjaan pada pertemuan arah pasangan dari berbagai arah mengingat posisi existing bangunan pada sisi Timur dan Barat miring 16 derajat. Pertemuan sudut antara 90 derajat dan 16 derajat inilah yang akan menimbulkan masalah dari sisi teknis pemasangan. Pola lantai menggunakan teknik cor ditempat dengan bahan terazzo dengan motif batik kawung. Selain berfungsi sebagai stopper pasangan lantai motif ini difungsikan sebagai penanda atau petunjuk area.

\section{Desain Display Penjualan}

Sistem display mengacu pada desain display yang fungsional, efisien dan efektif. Desain display secara fungsional dapat mendukung aktifitas perdagangan, mudah dalam perawatan, kuat, awet, aman dan bentuk display mencirikan lokalitas. Sistem display juga mampu mendukung terciptanya pengalaman ruang yang menarik bagi pengunjung pasar.

Material display menggunakan perpaduan besi (rangka utama), kayu pinus (case and table fixture), dan anyaman rotan sebagai penutup case fixturenya. Perpaduan beberapa jenis material ini bertujuan secara fungsional dan pencapaian tema. Display secara visual mempunyai ciri lokalitas dan mampu menjadi atraksi visual yang menariksehingga tercipta pengalaman ruang yang menarik bagi pengunjung pasar. Skema material dan bahan display adalah sebagai berikut,

Aspek fungsional sistem display dapat dicapai berdasarkan identifikasi jenis produk, perlakuan produk, kapasitas produk, dan sistem pelayanan. Sistem display yang tepat adalah jenis Case Fixture. Case Fixture adalah rak terbuka sebagai wadah produk dan dianjurkan pada sistem ini dapat dirangkai dalam beberapa komposisi tertentu sesuai dengan kebutuhan. Case Fixture dirancang dengan sistem modular, sehingga mampu diaplikasikan kedalam beberapa tipe kios dengan luasan yang bervariasi. Material yang digunakan pada sistem display adalah besi, kayu dan rotan. Dasar Pemikiran penggunaan material besi adalah karena tingkat fleksibilitas dan kekerasan yang tinggi. Besi digunakan sebagai rangka utama pembentuk display dengan menggunakan finishing cat jenis enamel. Bahan kayu yang digunakan adalah kayu pinus dengan finishing natural water based. Case Fixture dibuat membulat dengan tujuan untuk mereduksi terjadinya sudut yang dapat mengakibatkan memicu kerusakan pada buahbuahan yang dijual. Teknik konstruksi pada kayu menggunakan sambungan jenis dove tail, sehingga case fixture terbebas dari penggunaan paku. Material rotan digunakan sebagai penutup case fixture apabila pedagang menutup kiosnya. Perpaduan beberapa jenis material pada display bertujuan agar komoditi dapat menjadi atraksi visual yang menariksehingga tercipta pengalaman ruang yang menarik bagi pengunjung pasar.

\section{SIMPULAN}

Misi perancangan pasar tradisional secara umum adalah menyediakan ruang-ruang yang nyaman, aksesibel, dan mewadahi interaksi sosial untuk aktivitas ekonomi dan sosial. Pasar menjadi tempat komunitas (pedagang) dalam mengembangkan diri. Keberhasilan perancangan pasar tradisional juga bisa berkontribusi bagi penguatan karakter lokal dari komunitas tersebut, untuk kemudian menjadi identitas kota. Kenyamanan ditandai dengan pasar yang terlihat bersih, tertata, lapang, tidak pengap dan sumpek, serta terang. Aksesibilitas ditandai dengan mudah dijangkaunya kios-kios oleh pengunjung. Ruang sosial terlihat dengan adanya ruang untuk berinteraksi sosial antara pengunjung, pedagang, dan pelaku lainnya. Salah satu tujuan desain interior adalah memperkaya nilai estetika dan meningkatkan aspek psikologis dari ruang interior. Tolok ukur perancangan desain interior adalah mewujudkan gubahan ruang untuk manusia, untuk kepentingan 
tersebut dari sisi manusia sebagai pengguna desain. Dengan demikian desain interior bukan lagi sebuah karya yang hanya bisa dinikmati karena kemegahan atau keindahannya saja, tetapi yang lebih penting adalah mampu menjadi solusi bagi masalah-masalah lingkungan binaan secara utuh. Begitu juga dengan desain interior Rumah Budaya Pasar Gedhe sebagai destinasi pariwisata Kota Solo.

\section{DAFTAR PUSTAKA}

Ahmad Fajar Ariyanto, 2017, Identifikasi Pasar Gedhe Hardjonagoro sebagai Destinasi Pariwisata Kota Solo,

Francis D.K. Ching, 1996, Ilustrasi Desain Interior, Jakarta: Penerbit Erlangga

Munirwanto, 2009, "Perancangan arsitektur tersebut berjudul Konservasi Kawasan Segitiga"Stasiun-Benteng-Gede (SBG)" Kota Solo, Teknik Arsiktektur", Fakultas Teknik Universitas Muhammadiyah

Palmer, Mickey, 1981, The Architect's Guide to Facility Programming (New York: The American Institute of Architects Washington, D.C. and Architectural Records Book

Sunarmi, Ahmad Fajar Ariyanto, dalam Buku Ajar Matakuliah Desain Interior Public (Surakarta: UNS Press, 2012, Edisi 1)

\section{Website}

www.surakarta.go.id, diakses 23 Februari 2016 pukul 07.25 WIB

http://simpasarsurakarta.diginetmedia.co.id/v2/ profil/visi_misi, diakses 15 Maret 2016 pukul 22.40 WIB

http://simpasarsurakarta.diginetmedia.co.id/v2/ sambutan/index, diakses 15 Maret 2016 pukul 22.35 WIB.

www.pu.go.id, diakses tanggal 17 Maret 2016 pukul 06.30 WIB. http://www.ar.itb.ac.id/pa/wp-content/uploads/2007/ 11/201212geniuslocipasar.pdf, diakses tanggal 20 Pebruari 2016, pukul 06.20 WIB.

http://www.ar.itb.ac.id/pa/wp-content/uploads/2007/ 11/201212geniuslocipasar.pdf, diakses tanggal 20 Pebruari 2016, pukul 06.20 WIB.

http://www.ar.itb.ac.id/pa/wp-content/uploads/2007/ 11/201212geniuslocipasar.pdf, diakses tanggal 20 Pebruari 2016, pukul 06.20 WIB.

Electronic Theses and Dissertations Universitas Gadjamada, www.etd.repository.ugm.ac.id, diakses tanggal 25 April 2016 pukul 05.15 WIB

Jurnal Ilmiah Gema Teknik, Nomor 2/Tahun X Juli 2007, hlm. 111-118.http://

simpasarsurakarta.diginetmedia.co.id/v2/profil/ visi_misi, diakses 15 Maret 2016 pukul 22.40 WIB

http://simpasarsurakarta.diginetmedia.co.id/v2/ sambutan/index, diakses 15 Maret 2016 pukul 22.35 WIB.

\section{Surat Kabar Online}

Tribun News, 39 Pasar Tradisional di Solo Overload, 17 Februari 2014, diakses 29 Maret 2016 Pukul 03.55 WIB.

\section{Surat Kabar}

Solopos, edisi 20 Mei 2015.

\section{(Footnotes)}

${ }^{1}$ Munirwanto, Surakarta tahun 2009. Perancangan arsitektur tersebut berjudul Konservasi Kawasan Segitiga"StasiunBenteng-Gede (SBG)" Kota Solo, Teknik Arsiktektur Fakultas Teknik Universitas Muhammadiyah

${ }^{2}$ Ahmad Fajar Ariyanto, 2017, Identifikasi Pasar Gedhe Hardjonagoro sebagai Destinasi Pariwisata Kota Solo,

${ }^{3}$ Palmer, Mickey, The Architect's Guide to Facility Programming (New York: The American Institute of Architects Washington, D.C. and Architectural Records Book, 1981) hal 98-102

${ }^{4}$ Sunarmi, Ahmad Fajar Ariyanto, Buku Ajar Matakuliah Desain Interior Public (Surakarta: UNS Press, 2012, Edisi 1) hal.55

${ }^{5}$ Francis D.K. Ching, Ilustrasi Desain Interior ( Jakarta: Penerbit Erlangga, 1996) hlm.26 